\title{
A comprehensive review of adult enuresis
}

Hamed Akhavizadegan ${ }^{1,2}$; Jennifer A. Locke ${ }^{1}$; Lynn Stothers ${ }^{1,3}$; Alex Kavanagh ${ }^{1}$

${ }^{1}$ Department of Urological Sciences, University of British Columbia, Vancouver, BC, Canada; ${ }^{2}$ Urology

Department, Tehran University of Medical Sciences, Tehran, Iran; ${ }^{3}$ Principal Investigator, International

Collaboration On Repair Discovery (ICORD), Peter Wall Institute for Advanced Studies Scholar, University of

British Columbia, Vancouver, BC, Canada

Cite as: Can Urol Assoc J 2018 September 27; Epub ahead of print. http://dx.doi.org/10.5489/cuaj.5485

Published online September 27, 2018

$* * *$

\begin{abstract}
Nocturnal enuresis (NE) is a combined symptom of nocturia and urinary incontinence. In this review, we aim to summarize the current literature on NE in terms of its definition, diagnosis, and management. Recommended diagnostic evaluation of NE includes a focused history and physical examination, urinalysis, and when indicated, ultrasound examination, flow rate, urine volume chart, urodynamics, and cystoscopy. Therapeutic options include lifestyle modification and medications (i.e., desmopressin and anticholinergics).
\end{abstract}

\section{Introduction}

Gaining the ability to hold urine through the night is one of the developmental neuro-motor skills of a functioning bladder. ${ }^{1} \mathrm{NE}$ is considered a physiologic finding in children less than five years of age, but is considered abnormal in adults1. The International Continence Society (ICS) definition for nocturnal enuresis (NE) is any unintended voiding during night-time sleep. ${ }^{2}$ This definition lacks duration and frequency. In the current literature NE has been defined as one episode of nocturnal incontinence per 6 months or more, ${ }^{3}$ at least one time per week ${ }^{4}$ or one per month. ${ }^{5}$

Regardless of underlying pathology, patients with NE experience discordance between bladder compliance, sphincter efficiency and urine production overnight and often lack of awareness of a sensation to void. Many adults afflicted with NE are affected psychologically. The aim of this article is to further understand the definition, diagnosis, and management of NE.

\section{Classification}

There are two types of adult enuresis classifications (Table 1). ${ }^{1,2,6-8} \mathrm{NE}$ can be classified chronologically (i.e., primary versus secondary) or by symptomology (i.e., associated with LUTS or not). 


\section{Epidemiology}

Prevalence

In adults the prevalence of NE has been reported as 2-3\%. ${ }^{9-11}$ In females with voiding dysfunction and patients in nursing homes the prevalence is higher being $23 \%{ }^{12}$ and $39 \%$, ${ }^{13}$ respectively. In special populations, such as patients with Down syndrome, the prevalence is $17.2 \% .^{14-16}$

\section{Clinical course}

The most common form of NE is persistent (PPNE; never dry for more than 6 months) following by recurrent (PRNE; dry for more than 6 months before adulthood recurrence) then secondary (SNE. ${ }^{1}$ In general, NE is associated with a higher number of episodes overall and is less likely to resolve if diagnosed as an adult compared to childhood diagnosis. ${ }^{9-11}$ It is unclear if progression of NE into the adulthood is dependent upon the severity of childhood presentation or if adult NE arises de novo due to different physiologic mechanisms.

Risk factors

Neurologic disease, psychiatric medications and sleep apnea syndrome are risk factors for NE. ${ }^{6,12,17,18}$ Smoking, ${ }^{12}$ obesity, ${ }^{17}$ decreased physical activity, and hypertension ${ }^{18}$ are risk factors specifically identified in women. In men benign prostatic hyperplasia and outlet obstruction are significantly associated with higher prevalence of secondary NE. ${ }^{6}$ Interestingly, NE in childhood does not increase enuresis risk in adulthood. ${ }^{19}$

\section{Psychosocial consideration}

There is a significantly higher incidence of anxiety, depression, chronic fatigue and lower selfesteem in adults with NE as compared to the general population. ${ }^{6,15}$ Significant impact on psychosocial well-being has been noted in Western countries, ${ }^{2}$ Middle East countries, ${ }^{5}$ and Southeast countries. ${ }^{9}$ The relationship between psychological conditions and NE is complex. It is not fully established if these conditions result from NE or exacerbate NE.

\section{Physiology}

Pathophysiological mechanisms of nocturnal continence are outlined in Fig. 1. Briefly, through the night, a normal adult bladder can reach to volumes of 300 - 400 cc without needing to void due to bladder compliance and a closed outlet. Glomerular filtration typically decreases by $30 \%$ during the night and water reabsorption increases through the action of arginine-vasopressin. Thus, urine production decreases significantly. ${ }^{20}$ When one experiences increased volume of bladder to more than 300 - 400 cc a central mechanism awakens the person before unintentional voiding occurs. $^{12}$ 


\section{Etiology}

Etiologies of adult enuresis are classified as detrusor disorders, outlet issues, nocturnal diuresis and increased sleep arousal threshold (Table 2).

Multifactorial NE is common and can complicate clinical diagnosis. For example, diuretic use can increase nocturnal urine output and concurrent sedative use can increase sleep arousal threshold. Similarly, psychiatric medications such as olanzapine, clozapine and quetiapine, ${ }^{2,6}$ and risperidone ${ }^{21-23}$ can cause enuresis by several mechanisms including increased arousal threshold, increased urine production and decreased sphincter tone. ${ }^{6}$ Injured urinary sphincter during radical pelvic surgeries and concomitant polyuria caused by their continent pouch $^{6}$ and abnormal bladder and sphincter function and nocturnal polyuria in spinal cord injury ${ }^{2,6}$ are other examples of multifactorial NE.

\section{Assessment}

Initial presentation of NE is typically managed by primary care physicians. Further work up by a urologist is advised for adults presenting with complex or prolonged bothersome NE. ${ }^{6}$ Suggested urologic evaluation is detailed in Table 3.

Details of assessment in adult enuresis is depicted in Fig. 2.

\section{Management}

Psychosocial stress, and bothersome NE episodes typically prompt treatment. First-line treatment options include lifestyle modifications, behavioral therapy and medical therapy. Other interventions such as surgical intervention, neuromodulation, Botulinum toxin injection to bladder have been used in some patients but are typically reserved as second-line modalities.

\section{Lifestyle modification}

Caffeine and sedative avoidance are suggested as they alter sleep cycle function. Alcohol avoidance is suggested due to its effect as a diuretic. Weight reduction can be advantageous through its effects of improving sleep apnea syndrome, and regular physical activity are potential ways to decrease the episodes of NE. ${ }^{13,18}$

\section{Behavioural therapy}

Although there is data to support time-voiding q2hrs and alarm system in children for $\mathrm{NE}^{26}$ there is no data in young adults. Furthermore, timed-voiding has a limited role in elderly patients with NE due to decreased adaptive conditioning skills and effect on sleep disturbances. ${ }^{13,26}$

Unfortunately, compliance with enuresis alarm systems is low in the adult population with a high withdrawal rate; ${ }^{4,6}$ however, when desmopressin failed to control enuresis, adding an alarm system has been reported to increase the response rate by $33 \%{ }^{2}$

Adapted Dry Behavioral Therapy (ADBT) is a cognitive behavioral and prompted voiding therapy which includes close observation during sleep, waking up frequently during night (every one hour), alarm use and day-time timed voiding. Although it is effective, high cost and time commitment deter its use commonly. ${ }^{24}$ 
Despite successful results in children, behavioral therapy is not as effective in adults. ${ }^{6}$ In selected adult cases (infrequent bed wetting, normal sonography and cystometric capacity greater than $300 \mathrm{cc}$ ) it may have a contributive role. ${ }^{24}$

\section{Specific treatments}

First-line therapy after lifestyle changes and behavioral therapy includes treating identifiable pathologies (Fig. 3). In addition to specific therapy any psychiatric contributors such as depression and anxiety should be addressed as well. ${ }^{15}$

\section{Medical therapy}

In patients with NE with no defined etiology medical therapy is first-line. There are two classes of medications with supportive evidence: desmopressin and anticholinergics.

\section{Desmopressin}

Desmopressin has been accepted as first line therapy of idiopathic adult NE.2 Although some authors advocate to prescribe it only in the nocturnal polyuria variant of enuresis, ${ }^{3}$ currently it is the first treatment in adult NE with or without nocturnal polyuria.,

Most patients require at least 0.2 to $0.4 \mathrm{mg}$ of desmopressin per night; ${ }^{2,6}$ physicians should start at the low dose and titrate up. Patients with detrusor overactivity often require the higher dose ( $0.4 \mathrm{mg} /$ day) to show any benefit. ${ }^{5}$ Once the suitable dose is found, decreasing or withdrawal of drug invariably causes symptom relapse and is therefore not recommended. ${ }^{5}$ Informing the patient about needing long-term therapy and the likelihood of decreasing the dose as well as safety of long-term usage of the drug helps should be highlighted during discussion before starting desmopressin 3, 5 and 27. Water intoxication and hyponatremia are dangerous and life-threatening complications. Fluid restriction from evening until morning is an efficient method to prevent these adverse effects. These complications are more common in the elderly. It is wise to check a serum sodium level at short intervals in first weeks of treatment. ${ }^{27}$

\section{Anticholinergics}

In desmopressin non-responders, an anticholinergic medication can be added. In general there is good evidence for the safety of anticholinergics with urinary retention being a very rare side effect especially from younger population with NE. ${ }^{5}$ Imipramine as a peripheral anticholinergic and a drug with possible central effects have been shown to be effective in NE with polyuria. However, there are concern about its cardiac adverse effects in elderly patients. ${ }^{6}$ Watchful monitoring for urinary retention is important in patients utilizing anticholinergics.

Combination therapy is a long term and safe step in enuresis control. Discontinuation or decreasing dosage of drugs will often lead to symptom recurrence. ${ }^{5}$ If Desmopressin and an anticholinergic are not effective, Imipramine 25 to $50 \mathrm{mg}$ per day has demonstrated benefit, but is uncommonly prescribed by urologists due to need for ongoing close follow-up and poor compliance due to sexual side-effects. ${ }^{6}$ 
The flow of treatment steps for idiopathic nocturnal enuresis is outlined in Fig.4.

\section{Other treatments}

Minimal data exists to support surgical intervention for mono-symptomatic NE. ${ }^{12}$

Neuromodulation (peripheral and sacral) and botulinum toxin injection are capable of decreasing $\mathrm{NE}$ in patients with non-mono-symptomatic NE, however, there is no data supporting monosymptomatic NE. ${ }^{2}$

One randomized clinical study with 14 patients with refractory mono-symptomatic NE and abnormal detrusor function (over activity and reduced compliance) in each group has reported significant improvement in posterior tibial nerve stimulation arm in comparison to placebo. $^{29}$

\section{Conclusion}

Nocturnal enuresis is a symptom of urinary tract disorder or systemic disease. It requires a standard evaluation consisting of history and physical exam, urinalysis and when indicated urinary ultrasonography, Urine flow rate, frequency volume chart, urodynamic study and cystoscopy. It is recommended that general practitioners refer adults with NE to the urologist for this work-up because of its complexity.

There is minimal role for surgical intervention for this disease, except in specific populations. However, many patients benefit from long term Desmopressin. Anticholinergics can add benefit even in the absence of OAB symptoms. The role of neuromodulation, onabotulinumtoxin A and surgery are undefined in the literature. Behavioral techniques offer low risk intervention but their time commitment is considerable and they require a high degree of commitment on behalf of the patient to ensure compliance. Future studies should address these shortfalls in the literature to better manage adult patients with NE. 


\section{References}

1. Sakamoto K, Blavias GB. Adult onset nocturnal enuresis. The journal of urology, June 2001. Vol. 165, 1914-1917.

2. Hillary CJ \& Chapple C. The Evaluation and Treatment of Adult Nocturnal Enuresis. Curr Bladder Dysfunct Rep. (2014) 9:84-89.

3. Baek M, Park K, Lee HE, Kang JH, Suh HJ, Kim JH, Lee SD, Pai KS, Han SW, Park YH, Kim KD; Korean Children's Continence and Enuresis Society. A nationwide epidemiological study of nocturnal enuresis in Korean adolescents and adults: population based cross sectional study. J Korean Med Sci. 2013 Jul;28(7):1065-70. doi: 10.3346/jkms.2013.28.7.1065.

4. Ekinci O, Celik T, Unal S, Oktay G, Fevziye T, Ozer C. Nocturnal enuresis in sickle cell disease and thalassemia major: associated factors in a clinical sample. Int $\mathrm{J}$ Hematol. (2013) 98:430-436.

5. Yucel S, Ktlu O, Kukul E and Baykara M. IMPACT OF URODYNAMICS IN TREATMENT OF PRIMARY NOCTURNAL ENURESIS PERSISTING INTO ADULTHOOD. UROLOGY. 2004; 64 (5).

6. Abeygunasekera AM, Goonesinghe SK. Nocturnal Enuresis in Adults. Curr Bladder Dysfunct Rep. (2013) 8:217-222.

7. Bower WF, Sit FKY and Yeung CK. Nocturnal Enuresis in Adolescents and Adults is Associated With Childhood Elimination Symptoms. THE JOURNAL OF UROLOGY. 2006 Oct;176(4 Pt 2):1771-5.

8. Lee D, Dillon B, Lemack G. Adult onset nocturnal enuresis: identifying causes, cofactors and impact on Quality of Life. Low Urin Tract Symptoms. 2017 Jul 3. doi: 10.1111/luts.12183.

9. Yeung CK, Sihoe JD, Sit FK, Bower W, Sreedhar B, Lau J. Characteristics of primary nocturnal enuresis in adults: an epidemiological study. BJU Int. 2004 Feb;93(3):341-5.

10. Field JJ, Austin PF, An P, Yan Y and Debaun MR. Enuresis Is a Common and Persistent Problem Among Children and Young Adults with Sickle Cell Anemia. UROLOGY. 2008; 72 (1), 83.

11. Yeung CK, Sihoe JD, Sit FK, Diao M, Yew SY. URODYNAMIC FINDINGS IN ADULTS WITH PRIMARY NOCTURNAL ENURESIS. Journal of Urology. Vol. 171, June 2004. 2595-2598.

12. Campbell P, Li W, Money-Taylor J, Davies J, Gray T, Radley S. Nocturnal enuresis: prevalence and associated LUTS in adult women attending a urogynaecology clinic. Int Urogynecol J. 2017 Feb;28(2):315-320. doi: 10.1007/s00192-016-3099-0.

13. Howlett M, Gibson W, Hunter KF, Chambers T and Wagg A. Nocturnal Enuresis in Older People Where Is the Evidence and What Are the Gaps? J Wound Ostomy Continence Nurs. 2016;43(4):401-406.

14. Niemczyk J, von Gontard A, Equit M, Medoff D, Wagner C, Curfs L. Incontinence in persons with Down Syndrome. Neurourol Urodyn. 2017 Aug;36(6):1550-1556. doi: 10.1002/nau.23146.

15. Guragac A., Yilmaz S., Aydur E Mental and psychological characteristics of young adult males with primary nocturnal enuresis: A case-control observational study. Eur Urol Suppl. 2016;15(3);e540. 
16. Hyde TM, Deep-Soboslay A, Iglesias B, Callicott JH, Gold JM, Meyer-Lindenberg A, Honea RA, Bigelow LB, Egan MF, Emsellem EM and Weinberger DR. Enuresis as a premorbid developmental marker of schizophrenia. Brain (2008), 131, 2489-2498.

17. Madhu CK, Hashim H, Enki D, Drake MJ. Risk factors and functional abnormalities associated with adult onset secondary nocturnal enuresis in women. Neurourol Urodyn. 2017 Jan;36(1):188-191. doi: 10.1002/nau.22912.

18. Koo P, McCool FD, Hale L, Stone K, Eaton ED. Association of obstructive sleep apnea risk factors with nocturnal enuresis in postmenopausal women. Menopause, 2016; Vol. 23, No. 2, 175-182.

19. D’Ancona CAL, Lopes MHBM, Faleiros-Martins AC, Lucio AL, Campos RM and Costa JV. Childhood Enuresis Is a Risk Factor for Bladder Dysfunction in Adult Life? Neurourology and Urodynamics. 2012; 31:634-636.

20. Noh JY, Han DH, Yoon JA, Kim MH, Kim SE, Ko IG, Kim KH, Kim CJ, Cho S. Circadian rhythms in urinary functions: possible roles of circadian clocks? Int Neurourol J. 2011 Jun;15(2):64-73. doi: 10.5213/inj.2011.15.2.64.

21. Sunbul EA, Kosker SD, Cengiz FF, Yanartas O, Zincir SB. Risperidone-Induced Enuresis Nocturna. Journal of Mood Disorders. 2014; Volume: 4, Number: 4, 189-190.

22. Harrison-Woolrych M, Skegg K, Ashton J, Herbison P, Skegg DC. Nocturnal enuresis in patients taking clozapine, risperidone, olanzapine and quetiapine: comparative cohort study. Br J Psychiatry. 2011 Aug;199(2):140-4. doi: 10.1192/bjp.bp.110.087478.

23. Lopes R, Matias J, de Melo RC. Trazodone-induced nocturnal enuresis. Psychiatry Res. 2016 Jan 30;235:211-2. doi: 10.1016/j.psychres.2015.12.006.

24. HofmeesterI, Brinker AE, Steffens MG, Mulder Z, van Capelle JW, Feitz WF, Blanker $\mathrm{MH}$. Reference values for frequency volume chart and uroflowmetry parameters in adolescent and adult enuresis patients. Neurourol Urodyn. 2017 Feb;36(2):463-468. doi: 10.1002/nau.22955.

25. Yilmaz S., Alp B.F., Guragac A., Aydur E., Seckin B. Role of lumbosacral magnetic resonance 1maging on clinical evaluation of adult nocturnal Enuresis. Eur Urol Suppl 2015;14/2;e378.

26. Ouslander JG , Al-Samarrai N, Schnelle JF . Prompted voiding for nighttime incontinence in nursing homes: is it effective? J Am Geriatr Soc. 2001 Jun; 49(6):706-9.

27. Osterberg O, Savic RM, Karlsson MO, Simonsson US, Nørgaard JP, Walle JV, Agersø H. Pharmacokinetics of desmopressin administrated as an oral lyophilisate dosage form in children with primary nocturnal enuresis and healthy adults. J Clin Pharmacol. 2006 Oct;46(10):1204-11.

28. Kayıgil O, Aytaç B, Çakar KS \& Metin A. Clam ileocystoplasty in adult nocturnal enuresis. International Urology and Nephrology. 2001; 32: 647-649.

29. Raheem AA, Farahat Y, El-Gamal O, Ragab M, Radwan M, El-Bahnasy AH, ElGamasy AN, Rasheed M. Role of posterior tibial nerve stimulation in the treatment of refractory monosymptomatic nocturnal enuresis: a pilot study. J Urol. 2013 Apr;189(4):1514- 8. doi: 10.1016/j.juro.2012.10.059. Epub 2012 Oct 24. 
Figures and Tables

Fig. 1. Mechanisms of nocturnal continence.

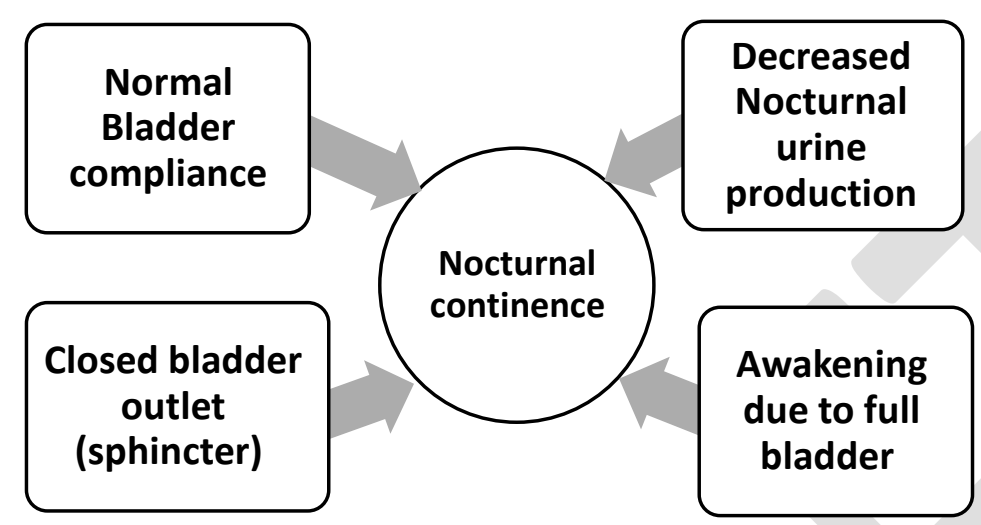

Fig.2. Assessment in adult enuresis. UDS: urodynamic study.

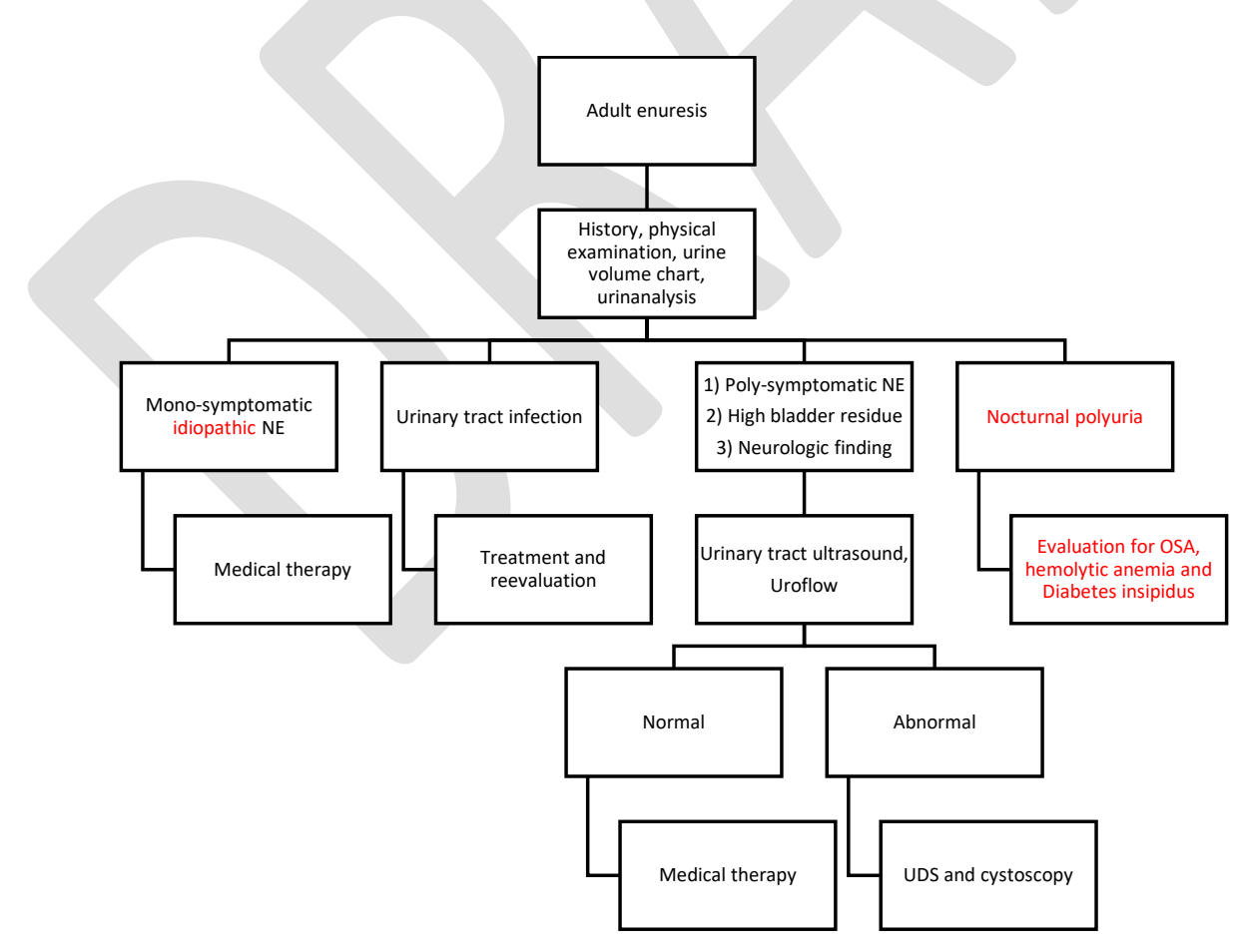


Fig. 3. Specific therapy for adult enuresis. ${ }^{*}$ Possible explanation for decreasing NE after midurethral sling placement is prevention of urinary leakage to proximal urethra and stress induced over-activity. ${ }^{12}{ }^{\wedge}$ Higher severity of enuresis in hemolytic disorders is associated with increased admission; therefore, efforts to manage chronic disease may help manage and better treat NE. *Although in nocturnal diuresis due to overproduction desmopressin is treatment of choice one should be cautioned in patients with kidney and liver disease water intoxication and hyponatremia these should also be individually addressed. 'Multifactorial NE is difficult to treat and best controlled by multimodal approaches and addressing all contributing etiologies. ${ }^{2,6}$ For example, empirically patients with spinal cord injury and neo-bladder after radical pelvic surgeries are managed by low-dose desmopressin, oxybutynin $5 \mathrm{mg}$ three times a day and catheterization before sleep. $^{2}$

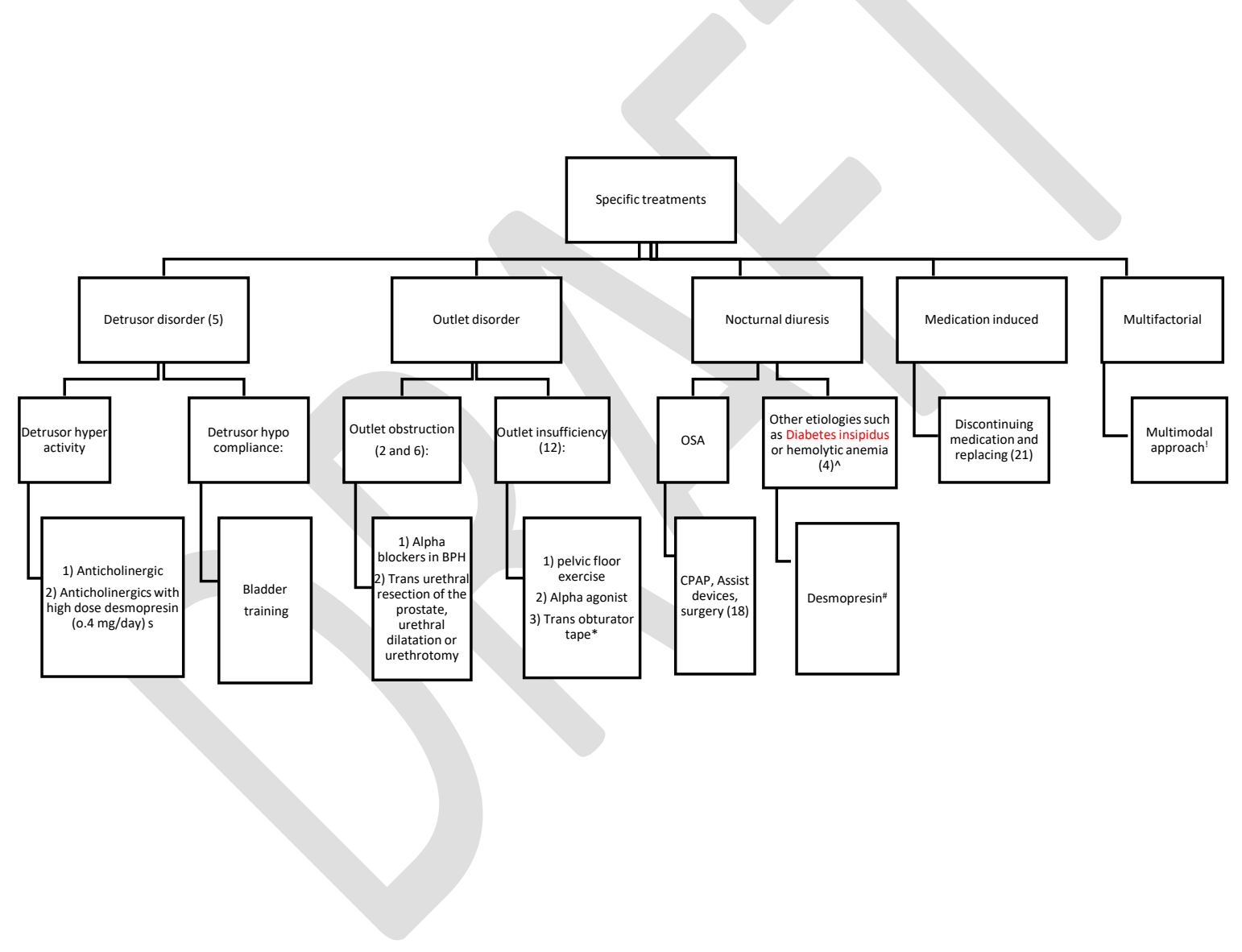


Fig. 4. Treatment steps for idiopathic nocturnal enuresis.

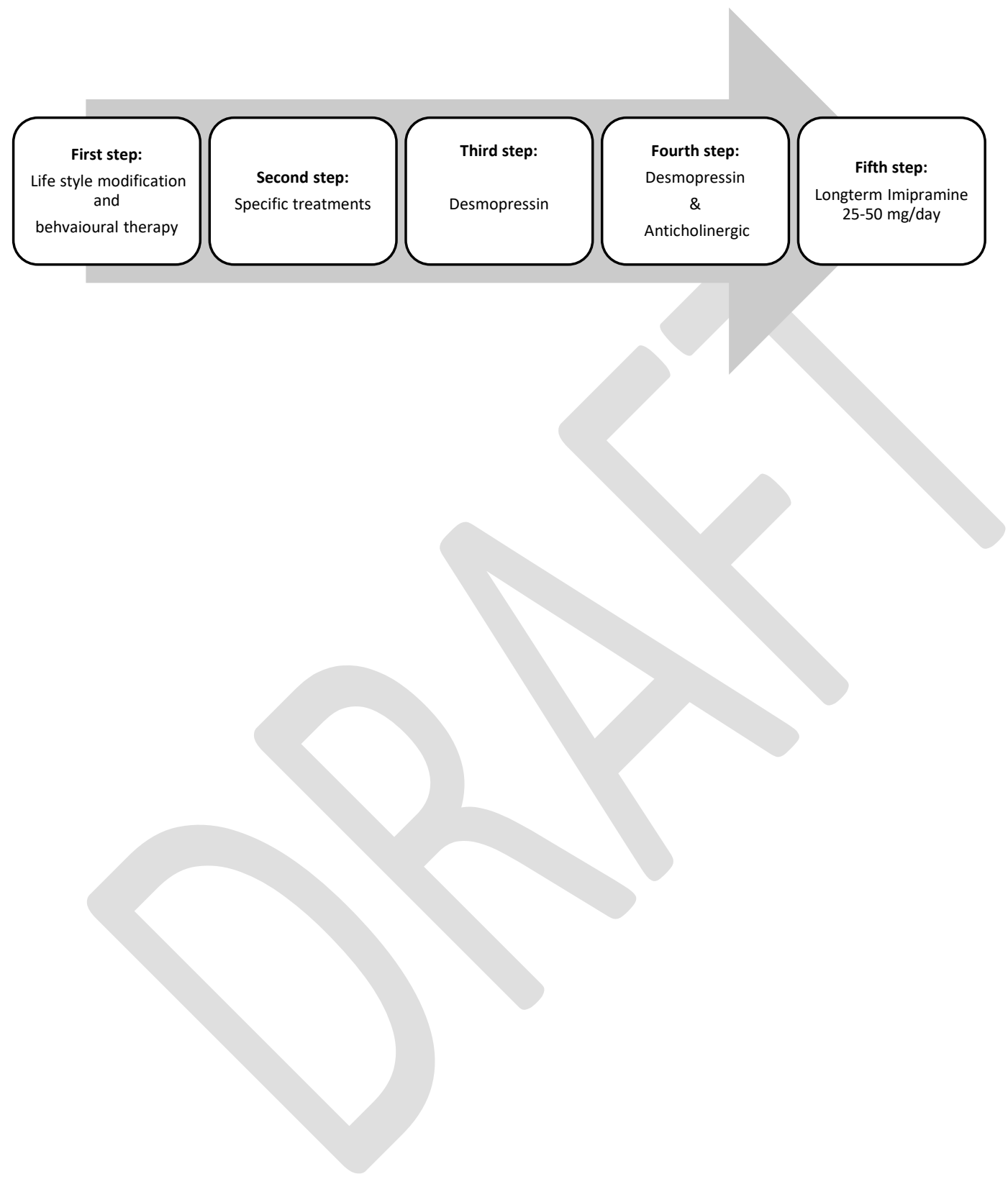




\begin{tabular}{|c|c|c|c|}
\hline & \multicolumn{2}{|c|}{$\begin{array}{c}\text { Primary NE (PNE) } \\
\text { (positive history in childhood) }\end{array}$} & \multirow{2}{*}{$\begin{array}{l}\text { Secondary } \\
\text { nocturnal } \\
\text { enuresis } \\
\text { (SNE) } \\
\text { (no evidence } \\
\text { of NE in } \\
\text { childhood) }\end{array}$} \\
\hline $\begin{array}{l}\text { Chronologic } \\
\text { classification }\end{array}$ & $\begin{array}{l}\text { Persistent (PPNE) } \\
\text { (never dry for more } \\
\text { than six months) }\end{array}$ & $\begin{array}{l}\text { Recurrent (PRNE) } \\
\text { (dry for more than } \\
\text { six months before } \\
\text { adulthood } \\
\text { recurrence) }\end{array}$ & \\
\hline $\begin{array}{l}\text { Symptomatic } \\
\text { classification }\end{array}$ & $\begin{array}{l}\text { Monosymptomatic NE } \\
\text { (the only symptom is } \\
\mathrm{NE} \text { ) }\end{array}$ & \multicolumn{2}{|c|}{$\begin{array}{l}\text { Polysymptomatic NE } \\
\text { (NE with other LUTS) }\end{array}$} \\
\hline
\end{tabular}

LUTS: lower urinary tract symptoms; NE: nocturnal enuresis.

\begin{tabular}{|c|c|c|}
\hline Etiology & Subtype & Disease \\
\hline \multirow[t]{2}{*}{ Detrusor disorder } & Detrusor over activity $^{12}$ & $\begin{array}{c}\text { Neurogenic bladder } \\
\text { Idiopathic detrusor overactivity }\end{array}$ \\
\hline & $\begin{array}{l}\text { Detrusor hypo- } \\
\text { compliance }^{12}\end{array}$ & $\begin{array}{c}\text { Scarred bladder } \\
\text { Chronic infection }^{1,6}\end{array}$ \\
\hline \multirow[b]{2}{*}{ Outlet issues } & Outlet obstruction $^{12}$ & $\begin{array}{l}\text { Neurogenic bladder, BPH, } \\
\text { urethral stricture }\end{array}$ \\
\hline & Outlet incompetence $^{\mathrm{I2}}$ & $\begin{array}{c}\text { Neurogenic bladder } \\
\text { Iatrogenic sphincter apparatus } \\
\text { injury } \\
\text { Antipsychotics }\end{array}$ \\
\hline \multirow[t]{2}{*}{ Nocturnal diuresis } & Renal disorder ${ }^{12,20}$ & \begin{tabular}{l} 
Chronic renal disorder \\
Renal medullary concentration \\
disorder (hemolytic disorders) \\
\multicolumn{1}{c}{ Diuretics } \\
Nephrogenic diabetes insipidus
\end{tabular} \\
\hline & Central disorder & $\begin{array}{l}\text { Obstructive sleep apnea } \\
\text { syndrome }{ }^{* 2,6} \\
\text { Chronic liver disease }^{12,20}\end{array}$ \\
\hline
\end{tabular}




\begin{tabular}{|l|c|c|}
\hline & & $\begin{array}{c}\text { Elderly }{ }^{12} \\
\text { Central diabetes insipidus }\end{array}$ \\
\hline \multirow{2}{*}{$\begin{array}{l}\text { Sleep arousal threshold } \\
\text { disorder }^{18}\end{array}$} & Sleep disorder & $\begin{array}{c}\text { Primary sleep disorder } \\
\text { Elderly }\end{array}$ \\
\cline { 2 - 3 } & $\begin{array}{c}\text { Alcohol, sedatives, antipsychotics } \\
\text { Reduced bladder } \\
\text { sensation }\end{array}$ & \begin{tabular}{c} 
Diabetes neuropathy \\
\hline
\end{tabular} \\
\hline
\end{tabular}

Obstructive sleep apnea (OSA) syndrome increases secretion of atrio-natrioretic peptide during sleep and this results in nocturnal polyuria. ${ }^{2,6} \mathrm{BPH}$ : benign prostatic hyperplasia.

\begin{tabular}{|c|c|c|c|}
\hline $\begin{array}{l}\text { Type of } \\
\text { assessments }\end{array}$ & Indication & Assessment & Details and findings \\
\hline \multirow{3}{*}{$\begin{array}{l}\text { Essential } \\
\text { assessments }\end{array}$} & \multirow{3}{*}{ In all patients } & History & $\begin{array}{l}\text { Lower urinary tract symptoms, past } \\
\text { medical and surgical history and } \\
\text { medications }{ }^{1}\end{array}$ \\
\hline & & Physical examination & $\begin{array}{l}\text { Focused neurological examination, } \\
\text { digital rectal examination and } \\
\text { bulbocavernous reflex }{ }^{1}\end{array}$ \\
\hline & & & To rule out urinary tract infection ${ }^{1}$ \\
\hline \multirow{4}{*}{$\begin{array}{l}\text { Optional } \\
\text { assessments }\end{array}$} & \multirow{4}{*}{$\begin{array}{l}\text { In patients with } \\
\text { inadequate results } \\
\text { with essential } \\
\text { assessments }\end{array}$} & Urine flow rate & $\begin{array}{l}\text { To screen silent obstruction or } \\
\text { hypocontractile bladder }^{2}\end{array}$ \\
\hline & & $\begin{array}{l}\text { Ultrasound of upper } \\
\text { and lower urinary tract } \\
\text { and post voiding } \\
\text { residue }\end{array}$ & $\begin{array}{c}\text { To evaluate upper tract damages and } \\
\text { lower tract efficiency in urine } \\
\text { elimination }^{2}\end{array}$ \\
\hline & & Urodynamic study & $\begin{array}{c}\text { Findings in SNE detrusor over } \\
\text { activity, hypo-compliant bladder } \\
\text { and silent bladder outlet } \\
\text { obstruction }{ }^{2} \\
\text { Urodynamic studies have less value } \\
\text { in PNE }\end{array}$ \\
\hline & & Cystoscopy & $\begin{array}{l}\text { In cases with bladder outlet } \\
\text { obstruction, posterior urethral valve } \\
\text { and urethral stricture have been the } \\
\text { most common findings }(6.7 \%)^{11}\end{array}$ \\
\hline
\end{tabular}

PNE: primary nocturnal enuresis; SNE: secondary nocturnal enuresis. 